\title{
Conservation of grassland leafhoppers: a brief review
}

\author{
Robert Biedermann ${ }^{1, *}$, Roland Achtziger ${ }^{2}$, Herbert Nickel ${ }^{3}$ and Alan J.A. Stewart ${ }^{4}$ \\ ${ }^{1}$ Landscape Ecology Group, Institute of Biology and Environmental Sciences, University of Oldenburg, 26111 \\ Oldenburg, Germany; ${ }^{2}$ Technische Universität Bergakademie Freiberg, Fakultät 2/Interdisziplinäres \\ Ökologisches Zentrum (IÖZ), AG Biologie/Ökologie, Leipziger Straße 29, D-09599 Freiberg, Germany; \\ ${ }^{3}$ Institut für Zoologie, Abt. Ökologie, Berliner Str. 28, D-37073 Göttingen, Germany; ${ }^{4}$ Department of Biology \\ and Environmental Science, School of Life Sciences, University of Sussex, Falmer, Brighton, UK; *Author for \\ correspondence (e-mail: robert.biedermann@uni-oldenburg.de; phone: +49-441-798-29-55; fax: +49-441- \\ 798-56-59)
}

Received 1 December 2004; accepted in revised form 17 June 2005

Key words: Auchenorrhyncha, Conservation, Froghoppers, Grassland, Hemiptera, Leafhoppers, Management, Planthoppers

\begin{abstract}
The leafhoppers, planthoppers and their allies (collectively known as the Auchenorrhyncha) are presented as a group of insects that are highly appropriate for studying grassland ecology and conservation, evaluating the conservation status of sites and monitoring environmental and habitat change. Semi-natural grasslands typically support dense populations and a wide range of species with diverse ecological strategies. Their numerical dominance in many grasslands means that they have considerable functional significance, both as herbivores and as prey for higher trophic levels. Population and assemblage studies are supported by good ecological knowledge about most species and modern identification keys. Hitherto, most studies have focused on the composition and structure of assemblages and how they are affected by conservation management. However, grasslands support many rare species with small and fragmented populations which deserve conservation attention in their own right, and recent work has started to reflect this. The effects of management on the composition and structure of grassland leafhopper populations and assemblages are described and an assessment is given of the main threats facing individual species and overall diversity. There is a need to synthesise the scattered literature on grassland leafhoppers, to provide a model for how the composition and structure of populations and assemblages respond to major environmental and anthropogenic gradients across large biogeographic areas. Such an analysis could help predict the impact of likely future changes in land use and climate.
\end{abstract}

\section{Introduction}

Conservationists have only recently started to use invertebrates to assess conservation site quality and as indicator taxa in terrestrial ecosystems (New 1995; Samways 2005). In temperate grasslands, Lepidoptera (Erhardt and Thomas 1991) and to a much lesser extent Orthoptera (e.g. Chambers and Samways 1998) have often been the favoured groups used for such purposes. This is in spite of the fact that such groups may not always be especially species rich or informative in grassland systems, although such habitats may contain particularly rare or vulnerable species. Other 
invertebrate taxa that are more diverse both in species and ecological strategies within grasslands, such as Coleoptera, Araneae and Hemiptera, have received far less attention in this respect. There are various reasons for this discrepancy, but most are to do with the level of public appeal and perceived (but not necessarily genuine) difficulties in identification associated with these smaller but more diverse groups.

The value of using leafhoppers to address fundamental questions in grassland ecology and conservation has been comparatively neglected until recently. With the exception of a few studies on single species (e.g. Raatikainen 1967; Whittaker, 1971, 1973; Biedermann, 2000, 2004) or small groups of species (Thompson 1978; den Bieman 1987), most attention has been focused at the multi-species assemblage level. Early pioneering work that characterized whole assemblages of grassland leafhoppers (Kontkanen 1950; Whittaker 1969; Waloff and Solomon 1973) provided the model for many subsequent studies. These early descriptive studies provided the foundations on which to build more experimental approaches (Morris 1971, 1981a, 1981b; Brown et al. 1992) and large-scale surveys (e.g. Whitcomb et al. 1994; Eyre et al. 2001). Most recently, grassland leafhoppers have been used to address central issues in theoretical ecology such as the relationships between species diversity, abundance and body size (Siemann et al. 1996, 1999) and important applied questions such as the likely impacts of habitat fragmentation (Biedermann, 2002) and global climate change (Masters et al. 1998; Whittaker and Tribe 1998). Whilst most previous work on grassland leafhoppers has focused on attributes of assemblages (species richness, diversity, proportion of specialist species etc.) and how they can be used as indicators of habitat quality and change, individual leafhopper species merit conservation in their own right; recent literature shows that this important principle is starting to be addressed (Biedermann 2000, 2004).

\section{The organisms - grassland leafhoppers}

Leafhoppers belong to an aggregate group of insects known as the 'Auchenorrhyncha' that covers the leafhoppers, planthoppers, froghoppers, treehoppers and cicadas. Throughout this review, we use the term 'leafhoppers' as shorthand for the taxonomically more precise, but less widely familiar, term Auchenorrhyncha. These insects belong to the order Hemiptera, the fifth most diverse insect order worldwide. They are relatively small (usually below $5 \mathrm{~mm}$ in length) and are entirely phytophagous, feeding on the phloem sap, xylem sap and mesophyll cell contents of vascular plants. Nault and Rodriguez (1985), Dolling (1991) and Denno and Perfect (1994) summarize information on their general biology and ecology.

The leafhoppers represent a highly appropriate group of insects for studying grassland biodiversity and conservation for several reasons:

(i) Numerical abundance: Along with the Diptera, Hymenoptera and other Hemiptera, the leafhoppers account for a significant proportion of the biomass and species richness of aboveground insects and other arthropods in natural and anthropogenic grasslands at temperate latitudes (Curry 1994; Tscharntke and Greiler 1995; Siemann et al. 1999). Densities in grassland frequently exceed 1000 individuals per $\mathrm{m}^{2}$ (Waloff 1980; Nickel and Hildebrandt 2003) and have been found to reach $8500 \mathrm{per} \mathrm{m}^{2}$ within Juncus tussocks (Rothschild 1966). More than forty species have been found to occur in single plots in meadows and pastures (Nikusch 1976; Nickel and Achtziger 1999).

(ii) Functional importance in grassland ecosystems: Leafhoppers act as consumers of plant assimilates or xylem sap contents. As such, they compete directly with other sap-sucking insects that exploit the plant transport system and indirectly with other insect and possibly vertebrate herbivores, although the latter interaction has not been studied critically. Many leafhoppers are also vectors of plant diseases such as viruses and phytoplasmas, a feature which is of great importance for crop production (Maramorosch and Harris 1979), but which has been little studied in natural ecosystems. Since phloem and especially xylem sap are among the poorest and most unbalanced of all insect food sources (Mattson 1980; White 1993), large amounts must be consumed in order to meet minimum nutritional requirements. Consumption rates of plant sap by leafhoppers are extremely high and may exceed 100 or even 1000 times their own body mass a day (Tonkyn and Whitcomb 1987). In view of these profound impacts on plants, one might expect leafhoppers to have 
significant effects on the competitive balance between plant species, ultimately affecting the relative dominance and species composition of plant species in natural vegetation, not least because many leafhopper species feed on abundant plants and may therefore increase plant diversity by leaving more resources to competitively inferior species (Nickel 2003).

Leafhoppers are also an important prey group for birds, ants, spiders and other predators, and they are hosts for a diverse assemblage of parasitoids including pipunculid flies, dryinid and mymarid wasps and stylopids (Waloff 1975; Andrzejewska 1979a, 1979b; Waloff and Jervis 1987; Guglielmino and Olmi 1997; Moreby and Stoate 2001). Finally, there is also some evidence that the prodigious amounts of liquid excreta produced by leafhoppers has significant effects on soil properties and may be important in accelerating nutrient cycling in grassland ecosystems (Andrzejewska 1979b).

(iii) Taxonomic diversity with stable nomenclature and good identification literature: The number of species typically found in grasslands is sufficiently large to enable meaningful statistical analysis of multi-species assemblage data and analyses of biodiversity, but not so large as to present a significant taxonomic challenge. In general, the taxonomy of the group is well advanced and stable. Although paucity of literature to facilitate identification has undoubtedly been an impediment to progress in the past, recent advances in the publication of authoritative but accessible keys and identification aids will undoubtedly improve this situation (Remane and Wachman 1993; Holzinger et al. 2003; Biedermann and Niedringhaus 2004).

(iv) Ecological diversity with good background of ecological knowledge: In addition to diversity of feeding modes, the leafhoppers display variation in a range of other ecological characteristics: degree of host plant specialism (extreme monophagy to broad polyphagy); voltinism (usually either one or two annual generations, but sometimes less or more); over-wintering stage (egg, nymph or adult); dispersal ability (flightless brachypters to dispersive macropters). Many of these features have been shown to be interrelated; for example, leafhoppers associated with ephemeral plant species (Novotny 1994a) and unpredictable or temporary habitats (Denno et al. 1991) tend to be more dispersive with higher proportions of macropterous individuals. In general, and perhaps especially for grassland species, ecological knowledge of individual species is well advanced (Nickel 2003), such that site data on assemblage composition and structure (species lists and relative abundances) can be interpreted with some precision and confidence.

(v) Standardized and simple/cheap methods for sampling and monitoring: A range of techniques are available for sampling leafhoppers in grasslands (reviewed by Stewart 2002). They vary from techniques that produce estimates of absolute density (suction sampling) to relative density estimates (sweep netting) but are amenable to standardization. The vertical structure of grassland habitats produces vertical stratification of the leafhopper fauna (Andrzejewska 1965). This means that the catches from different sampling techniques may diverge in species composition because they overrepresent particular vertical strata. Thus, sweep netting may result in an under-representation of certain taxa that reside low in the vegetation near the soil surface (e.g. species of Aphrodes, Streptanus, many Delphacidae) and are therefore more frequent in pitfall trap catches (Payne 1981; Cherrill and Sanderson 1994).

Differences in voltinism and seasonal phenology between species (Waloff and Thompson 1980) means that more than one sample per season is required to characterise the leafhopper assemblage at a particular site. In temperate grassland biomes, however, the season for adult leafhoppers generally lasts approximately four to five months so that two to three regularly spaced sampling occasions are normally adequate to provide a representative picture.

(vi) Responsive to environmental stresses and disturbance: Responses by species and assemblages after habitat changes tend to be very rapid (Morris 1981a, 1981b; Andrzejewska 1991). Indeed, in common with other grassland invertebrate groups that have short generation times and are responsive to changes in microhabitat and microclimate, the sensitivity of leafhopper assemblages to minor changes in management is very high. In this context, they may be better indicators of habitat change generally (and measures of restoration success) than plants (Mortimer et al. 1998).

Community parameters such as the number of species and individuals, as well as the proportion 
of specialists and generalists, can be measured with relative ease and therefore become useful parameters for biodiversity and conservation assessment and monitoring habitat change (e.g. Achtziger 1999; Bouchard et al. 2001).

\section{Habitat factors and interrelations}

The structure of grassland leafhopper assemblages is shaped by several factors, some of which may interact; in particular, climate, soil, vegetation and management (Figure 1). On a local scale, populations of leafhoppers are mainly influenced by the composition and physical structure of the vegetation. Indeed, leafhoppers reflect these two properties of the vegetation rather well, in contrast to other invertebrate groups that are more dependent either upon vegetation composition (herbivorous groups such as Curculionidae and Agromyzidae) or its physical structure (such as Araneae) (Gibson et al. 1992). Species richness and abundance are often positively correlated with plant diversity, height and spatial complexity (e.g. Murdoch et al. 1972; Morris 1990; Denno and Roderick 1991; Denno 1994; Achtziger 1995, 1997). The mechanism behind this is that greater structural complexity provides a wider diversity of niches and greater total habitat space. In turn, vegetation composition and structure is controlled mainly by soil parameters such as moisture, nutrient status and $\mathrm{pH}$, as well as levels of disturbance (e.g. trampling by cattle) and management, all of which indirectly affect leafhoppers.

Leafhoppers exhibit predictable responses to habitat succession (Hollier et al. 1994; HuuselaVeistola and Vasarainen 2000). Mobile, bi- or multi-voltine species predominate in early successional stages. These species tend to be replaced in the later stages of succession by univoltine and more sedentary species. There are parallel changes in other traits as succession advances, such as a shift from macroptery to brachyptery (both within and between species; Denno et al. 1991) and a change in the balance from host plant generalists to specialists (Novotný, 1994b).

Many studies show that grassland leafhopper species richness is negatively correlated with habitat disturbances such as fire (Morris 1975; but see also Panzer and Schwartz 2000) and the intensity of land use (e.g. cutting frequency), with different responses by generalists and specialists (e.g. Novotný 1991; Nickel and Achtziger 1999, 2005; Nickel and Hildebrandt 2003). In fact, certain species are especially associated with, and are therefore useful indicators of, disturbance (Andrzejewska 1962).

\section{Effects of habitat management}

Most temperate grasslands are mid-successional plagioclimax communities that, without active management, are vulnerable to scrub invasion and will eventually develop into woodland. Manage-

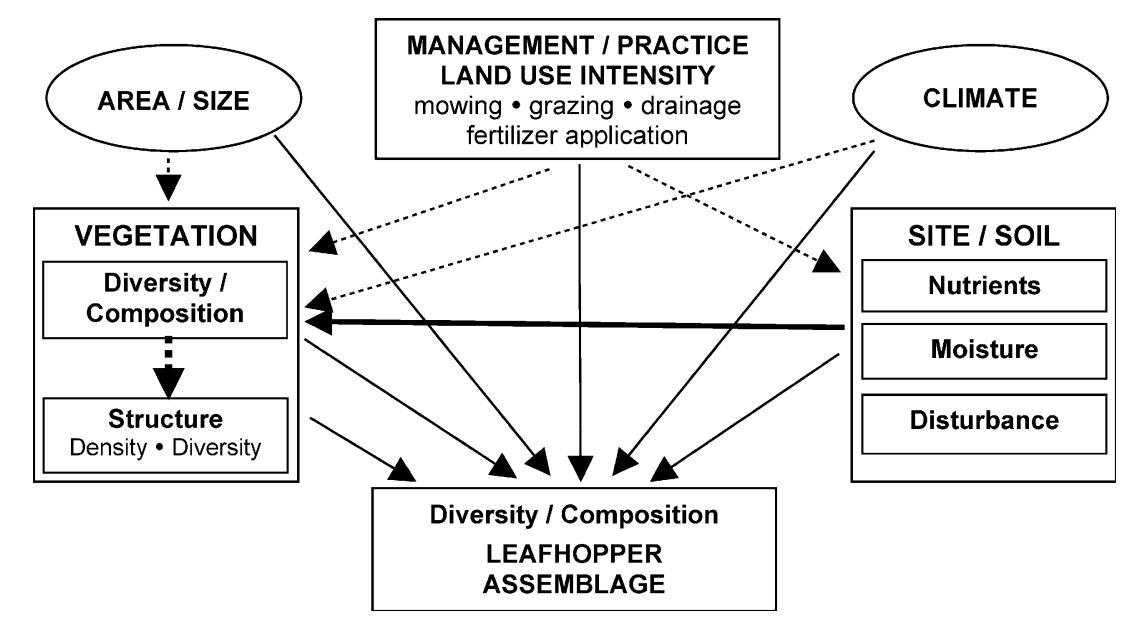

Figure 1. Schematic diagram of interacting habitat factors that directly (solid line) or indirectly (dashed line) influence the number of species and the composition of local leafhopper assemblages in grassland ecosystems. 
ment methods generally attempt to arrest or reverse this process and include various types of livestock grazing, mechanical cutting of the vegetation, fire and, under certain circumstances, water level control. In general, the abundance, species richness and diversity of leafhopper assemblages respond negatively to any management (such as grazing or cutting) that reduces the height, and therefore structural complexity, of the vegetation. However, this is a gross simplification of a complex pattern of responses.

Firstly, whilst the majority of species respond negatively to heavy grazing, there are some species whose densities are higher in short swards; on calcareous grassland, the ratio was 22:2 (Morris 1971). Mechanical cutting has a similar impact (Morris 1981a, 1981b), although the effect is more pronounced because, compared to grazing, it is more immediate and catastrophic and abruptly covers a wide area without leaving any tall grass patches as refuges. It does not necessarily follow that the species that favour grazing or cutting are ones with low conservation value. Some rare calcareous grassland specialist species appear to be dependent upon the high temperature microclimatic conditions produced by short sward vegetation on steep sun-facing slopes (Alexander 2003).

Secondly, the outcome of either form of management depends substantially on its timing in relation to the seasonal phenology of the constituent leafhopper species in the assemblage. Thus, autumn and winter grazing promotes larger numbers of leafhopper individuals and species compared to spring and summer grazing (Morris 1973). Similarly, mechanical cutting in May has far less effect on numbers and diversity of leafhoppers than cutting in July (Morris 1981a), mainly because the later date coincides with peak summer abundance of the adults. Further subtleties of response are produced by the various ways in which the number and phenology of generations exhibited by individual species interacts with the timing of management.

Thirdly, there are several other facets of any grazing/cutting management regime that are likely to have profound effects on the outcome for leafhoppers. These include the treatment intensity (density of grazing animals or height of cut), the frequency and duration of application (number of times per year and for how long) and, in the case of grazing, the type and breed of livestock used. Perhaps surprisingly, virtually none of these subtleties have been examined in any critical way. This is an area that would repay further investigation.

Finally, a distinction needs to be made between the immediate or short-term responses to vegetation management described above and long-term responses mediated through changes in vegetation composition, involving the occurrence of host plants and the microclimatic conditions they produce. Whilst suspension of grazing may benefit leafhopper densities and species richness in the short term, permanent removal of grazing will leave many grassland sites vulnerable to successional processes which eventually result in a decline in vegetation diversity and dominance by woody shrubs and, ultimately, trees. This in turn will have knock-on effects on the leafhopper assemblages present.

Although a high proportion of grassland leafhoppers are monophagous or narrowly oligophagous (Nickel 2003), most species are very sensitive to the nutritional quality of their host plants, especially nitrogen content. In fact, certain authors have regarded some species more as nutrition specialists rather than host plant species specialists (Prestidge 1982; Prestidge and McNeill 1982), focusing their feeding and oviposition activities in both space and time on plants with 'preferred' leaf nitrogen levels. Much evidence now exists that both the density and species composition of grassland leafhopper assemblages are strongly influenced by nutrient enrichment (Prestidge 1982; Sedlacek et al. 1988; Haddad et al. 2000) and that plant nutritional quality can influence the outcome of interspecific competitive interactions (Denno et al. 2000). More complex effects on leafhopper species composition and density result from interactions between different soil nutrients (and the formulations in which they are applied) and soil $\mathrm{pH}$, again mediated through the vegetation (Sedlacek et al. 1988; Morris 1992).

In summary, whilst both vegetation and soil parameters are directly affected by management, the diversity and structure of local leafhopper assemblages are controlled both by the direct effects of management (e.g. cutting, grazing) and indirect effects mediated through changes in the species composition, structure and nutritional quality of the vegetation. 


\section{Conservation status of grassland leafhoppers}

Few grassland leafhopper species are recognised as rare or endangered in official red lists. At a global scale, only three leafhopper species are listed in the IUCN Red List of Threatened Species (IUCN 2004): all are periodical cicadas in the genus Magicicada which are associated with trees. In general, the knowledge about the conservation status of leafhoppers is weak by comparison with other insect groups such as butterflies, Orthoptera and Odonata.

Only a few countries have published national red data listings for leafhoppers. In Germany, a national red data book (Remane et al. 1998) is supplemented by regional lists for four federal states (Witsack 1995; Nickel and Sander 2001; Walter et al. 2003; Nickel 2004). Kirby (1992) reviewed the scarce and threatened species in Great Britain; several grassland species were deemed to be potential candidates for Red Data Book status but lacked sufficient supporting information. Red data book listings of leafhoppers for other European countries are limited to selected regions or species: Carinthia in Austria (Holzinger 1999), South Tyrol in Italy (Remane 1994; Schedl 1994) and just three species in Sweden, none of which are associated with grasslands (Gärdenfors 2000).

\section{Threats to grassland leafhoppers}

As for other insect groups, major threats to grassland leafhoppers act on different spatial and temporal scales: habitat change and destruction is the most serious at the local scale, fragmentation operates at the landscape scale, while climate change and invasive species apply at regional through to global scales.

\section{Habitat change and land use}

Threats to grassland leafhopper species at the local scale are mainly associated with direct destruction or deterioration of habitats and important microhabitat conditions. Several studies show negative effects on species occurrence, community structure and diversity due to agricultural intensification or intensive management practices, e.g. mowing, grazing and fertilization (Morris 1981a; Prestidge
1982; Sedlacek et al. 1988; Novotný 1991; Nickel and Hildebrandt 2003; Nickel and Achtziger 2005). In most cases, this operates through direct and indirect changes to the composition and structure of the vegetation (including loss of food plants) and associated micro-climatic conditions. Even minor changes in these features may bring about declines or extinctions of local populations. Intercorrelations between many of these habitat features means that causal relationships between potential threats and declines in individual leafhopper species are often hard to establish unequivocally.

As an example, 265 leafhopper species are registered in the Red Data Book of endangered species for Germany (only categories "threatened by extinction", "strongly threatened", "threatened", "potentially threatened") (Remane et al. 1998). Out of these, 117 species inhabit grassland ecosystems: 22 species (18.8\%) primarily inhabit extensive grasslands, 36 species inhabit wet grassland and 59 species $(50.4 \%)$ mainly live on dry grassland types such as dry meadows and lawns (Nickel et al. 1999). The main causes of decline for endangered grassland leafhopper species in Germany are either the direct destruction of the habitats due to anthropogenic infrastructure (urban development, road construction etc.) or the altering of habitat conditions due to changes in land use or management practices (Figure 2). Agricultural intensification (increased frequency of cutting, fertilization) mainly affects species of extensive grassland $(15$ out $22 \mathrm{spp} .=68 \%)$ and wet grassland $(83 \%)$, whereas the abandonment of historical management practices such as sheep grazing on sunny slopes causes a decline mainly in species of dry grassland (41 out of 59 species $=69 \%$ ). Nearly all species of wet or moist meadows are negatively affected by artificial drainage or other changes in the water table (Figure 2).

Eutrophication by atmospheric nitrogen may alter the competitive balance between plant species in nutrient-poor habitats where nitrogen is usually limiting for plant growth. As an example, this has been suggested as a partial cause of the spread and increasing dominance by Brachypodium pinnatum in calcareous grasslands (Bobbink et al. 1998), although the magnitude of such impacts varies geographically (Wilson et al. 1995). Several rare leafhoppers are monophagous on this plant species 


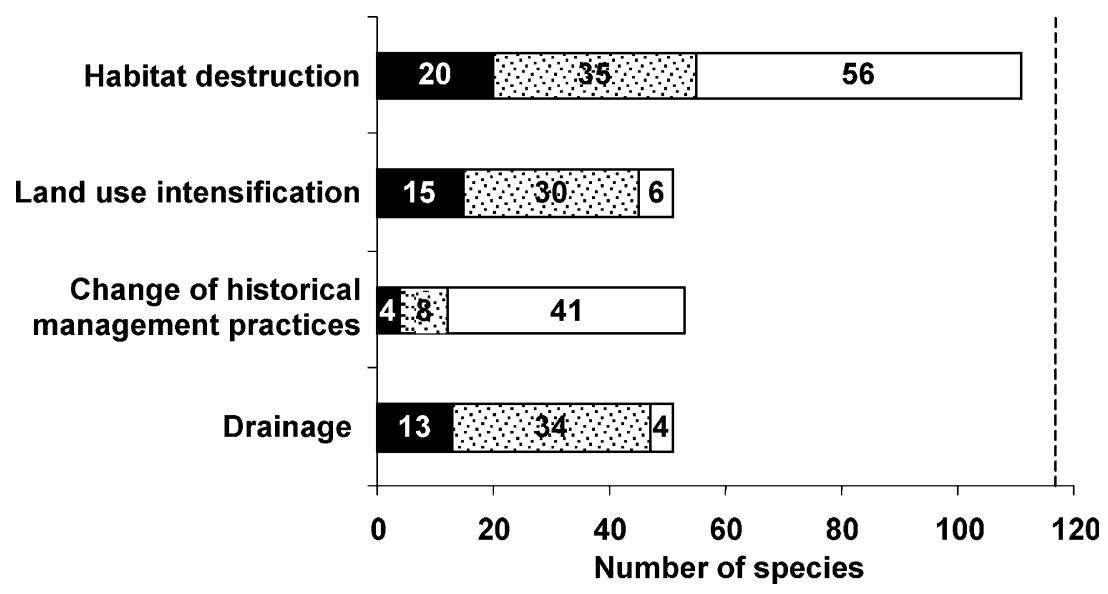

Figure 2. Factors threatening grassland leafhoppers in Germany. Figures inside, and width of, bars indicate the number of species affected in three different habitat types (solid = low-intensity grassland species - no particular moisture preference; dotted = wet grassland species, white $=$ dry grassland species). The dashed vertical line indicates the total number of threatened grassland species in Germany (data from Nickel et al. 1999).

(e.g. Ribautodelphax pungens and Eurysanoides douglasi in England) and will therefore be directly affected by any such changes or indeed by any attempts to prevent its further spread.

\section{Fragmentation and habitat loss}

At the landscape level, habitat fragmentation describes the decrease in number and size of suitable habitat patches for species (e.g. Harrison and Bruna 1999; Huxel and Hastings 1999; Tscharntke and Brandl 2004). Concern has increased in recent decades about the potential effects of ongoing habitat fragmentation by human activities, especially in cultural landscapes (Settele et al. 1996). Most grassland habitats have been fragmented to some extent. Recent studies have shown that leafhopper species are affected by the effects of fragmentation, especially reduced habitat area, small habitat patches being associated with an increased risk of local extinction for many species (Biedermann 2000; Cronin 2004). In a review of existing studies on leafhopper populations in fragmented landscapes, Biedermann (2002) found that a high proportion of species were area-sensitive. However, species differ widely in their response to habitat fragmentation (Biedermann 2004), some species being only marginally affected, whilst others require large areas for persistence. Furthermore, the import effect of habitat connectivity on the occurrence and persistence of grassland leafhopper species has been highlighted (Biedermann 2002; 2004; Cronin 2004).

\section{Climate change}

There has been much discussion of how predicted global climate change will affect the distribution and population dynamics of insects, and thence the structure and composition of insect communities and interactions between trophic levels (e.g. Harrington et al. 1999; Hughes, 2000; Bale et al. 2002). It is likely that grassland leafhoppers will also be affected by, for instance, increasing temperature, elevated $\mathrm{CO}_{2}$ and changing precipitation patterns, although relatively few empirical studies to date have analysed potential effects on populations and communities.

Insect performance data from altitudinal transects have been used to model the effects of predicted temperature changes. When applied to the xylem-feeding spittlebug Neophilaenus lineatus, this approach showed that a rise in temperature will probably change both seasonal phenology and distribution in this species (Whittaker and Tribe 1996; 1998; Fielding et al. 1999). In addition, this spittlebug exhibited reduced performance during nymphal development when exposed to elevated $\mathrm{CO}_{2}$ (Brooks and Whittaker 1999). Karban and Strauss (2004) have associated the observed 
northwards range shift in California shown by another spittlebug, Philaenus spumarius, with a rise in temperature over the last two decades. At the community level, Masters et al. (1998) found that experimentally simulated summer droughts do not necessarily result in a decrease in abundance of leafhoppers on a calcareous grassland. However, they observed an enhanced mortality during hibernation, when simulating warmer winter temperatures.

Although the implications for conservation of these results are not yet clear, it seems likely that climate change may potentially be a threat to leafhopper species, especially those with small ranges (e.g. confined to mountain tops) or species that are strongly dependent upon particular microclimates within their habitats. Furthermore, indirect effects mediated through changes in host plant quality or distribution may reduce the amount and suitability of habitats for leafhoppers. Disruption of trophic relationships because plants, insect herbivores and their natural enemies may respond differently to climate change (Davis et al. 1998; Voigt et al. 2003) could lead to unpredictable and idiosyncratic changes in the distribution and abundance of leafhopper species.

\section{Biological invasions}

Anthropogenic range expansions have become one of the leading issues in present-day ecology (e.g. Drake et al. 1989; Di Castri et al. 1990; Mooney and Hobbs 2000). Biological invasions can induce changes in local leafhopper food webs both through direct interactions (competition with an introduced herbivore, predation, parasitism) and through indirect interactions (a novel insect-plant feeding relationship, competition between plants, disease outbreaks amongst host plants).

There are rather few well-documented examples of direct effects involving leafhoppers. The recent spread of the orb-web spider Argiope bruennichi and the delphacid planthopper Muellerianella fairmairei may have reduced native grassland leafhopper populations, but effects have not been adequately studied. A change in dominance between competing herbivore species can be brought about through the medium of a shared parasitoid. The best case so far amongst leafhoppers involved two syntopic pest species of the typhlocybid genus
Erythroneura attacking grapevines. E. variabilis was able to successfully invade Californian vineyards and out-compete the native E. elegantula because it brought with it an egg parasitoid (Anagrus epos, a mymarid wasp) that switched to preferentially attacking the newly-encountered alternative host (Settle and Wilson 1990). Although not an example from grasslands, such indirect interactions might well apply but go undetected amongst non-pest grassland fauna.

It is easy to see how invasion by an alien plant species could have far-reaching consequences for native leafhoppers. Many examples exist of where invasive plants out-compete native species, with consequences for the associated invertebrate fauna of both the invading and the displaced plant species. As an example the invasive bermudagrass Cynodon dactylon has invaded the southwestern German upper Rhine plain, suppressing native psammophilous grasses like Corynephorus canescens and their associated leafhoppers. This plant probably originates from the Mediterranean region or Africa and has been introduced into warmer parts of central Europe. It seems to have brought part of its herbivore load, including the planthoppers Toya propinqua and the leafhopper Recilia schmidtgeni (Nickel 2003). Similarly, the Nearctic saltmarsh grass Spartina alterniflora has given rise to polyploid hybrids with the Old World Spartina maritima, which in turn is now invading intertidal saltmarshes along the European coasts (Ainouche et al. 2004). Interestingly, the delphacid planthopper Prokelisia marginata, a native of the eastern United States, has recently been found in saltmarshes in Slovenia (Seljak 2004) and Portugal, where it lives monophagously on the native cordgrass Spartina maritima. Many more examples could be cited, but a particular threat is presented in many European river floodplains by a number of invasive tall herbs and shrubs, notably Heracleum mantegazzianum, Impatiens glandulifera, Solidago spp., Fallopia japonensis and Amorpha fruticosa. These species locally outcompete important grass hosts of leafhoppers and other insects, such as Phalaris arundinacea and Phragmites australis (see Kowarik 2003).

As in plants and many other animal groups (Crosby 1986), it is striking that the majority of introductions of grassland leafhoppers into novel biogeographic zones clearly took place from Europe to North America rather than vice versa. 
Hamilton (1983) lists more than 20 grassland cicadellid leafhoppers in North America that have been introduced from the Old World, many of which are common in anthropogenic meadows and pastures throughout the temperate zone of the Nearctic. This list includes widespread Palearctic species such as Aphrodes bicincta, Anoscopus albifrons, A. serratulae, Graphocraerus ventralis, Athy-sanus argentarius, Elymana sulphurella, Erras-tunus ocellaris and Arthaldeus pascuellus. Very few Nearctic species have successfully colonised in the opposite direction, the recent arrival of Prokelisia marginata in Europe being an exception. Whether any of these biogeographic transfers will result in competition with the resident native fauna remains to be seen.

There are a few reported cases of rapid range expansions amongst grassland leafhoppers. For instance, the typhlocybine leafhopper Zyginidia scutellaris has extended its range from southern and western Europe through most parts of Germany within a few decades, the same being true for the delphacid planthopper Muellerianella fairmairei (Nickel 2003). After at least fifty recorded years of being confined to southern English coastal habitats, the leafhopper Athysanus argentarius has rapidly expanded its range northwards, inland and into new habitat types (Stewart 1999; Kirby et al. 2001). Nothing is known so far about the impact of these expansions on community structure and composition, but they could include direct or diffuse competition with other grassland leafhoppers and other phytophagous insects.

\section{Responses of grassland leafhoppers to conservation measures}

In general, grassland leafhopper species are not the intended targets of specific conservation measures taken to preserve or enhance biodiversity or populations of endangered species. However, they may nevertheless benefit from habitat improvements actually made for other taxa that have a higher profile and more public support (e.g. butterflies, grasshoppers, orchids, wading birds in wet grasslands). Much effort has therefore been directed into assessing the responses of individual leafhopper species (occurrence abundance etc.) and assemblage parameters (richness, diversity, proportions of threatened or specialist species etc.) to the range of conservation management measures that are typically adopted in grasslands. Table 1 shows that the various components of agricultural extensification (reduced fertilizer and pesticide inputs, reduced grazing or mowing intensity and frequency) generally lead to an enhancement of overall leafhopper diversity and the proportion of specialist or stenotopic species. This works at least partly through an increase in vegetation structural diversity and a reduction in the frequency and severity of disturbance, although some species benefit from high disturbance. Of course, there are many subtleties behind this general pattern (e.g. the effect of the timing of management operations such as grazing or mowing) and there are opportunities for considerable fine-tuning to create spatial heterogeneity at a local or landscape scale (e.g. through rotational grazing).

It is often the case in conservation that the particular habitat and management requirements of one taxonomic group may lead to conflicts with the interests of other groups that are present within the same site. This problem is particularly acute where there are significant populations of important species concentrated in small sites. In grasslands, the details of management prescriptions, for example on the frequency or seasonal timing of grazing or mowing operations, may not be suitable for all taxa. An obvious example is the fact that leafhopper assemblages are most diverse when the vegetation is ungrazed or only lightly grazed. This conflicts with the specific microclimatic requirements of certain thermophilous butterflies that require short swards (Thomas 1983; Oates 1995) and the need for grazing to help maintain a plant community that is species-rich and sustains important rare species such as orchids. In such cases, one potential solution is to produce heterogeneity in sward height at different spatial scales, although this is usually difficult to create and maintain.

\section{Future perspectives}

Significant challenges and opportunities lie ahead for conservationists interested in the preservation of this group of insects within grasslands. Although leafhoppers are not the direct targets of environmental improvement schemes, they nevertheless 


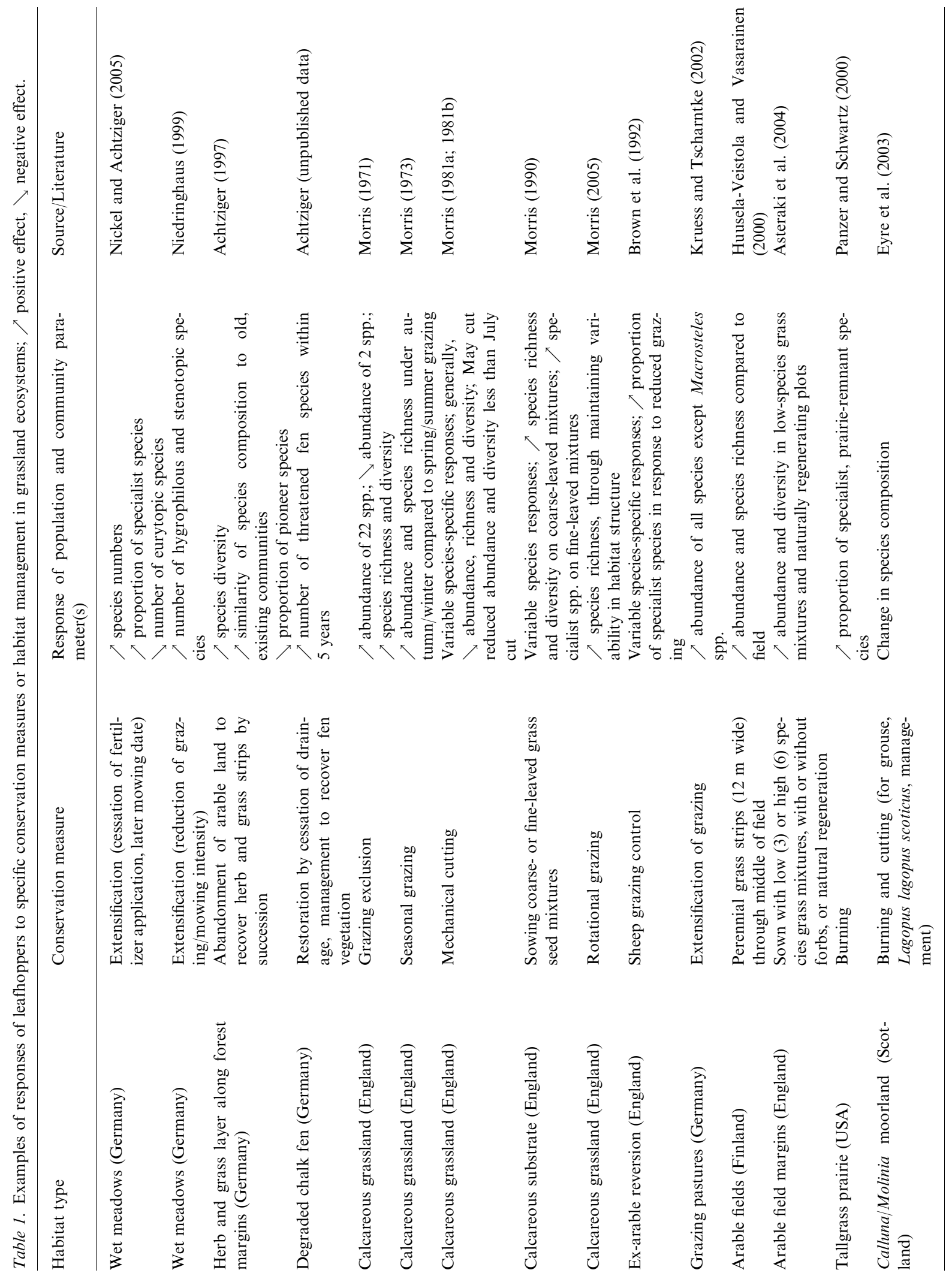


contribute to the overall biodiversity of an area. From the foregoing account, it is clear that leafhoppers are likely to benefit from a general shift towards less intensive farming systems in which fertilizer and pesticide inputs are reduced and grazing systems are low-intensity. Consideration of how such taxa respond to the various components of agricultural 'extensification' is an important current research area. This is especially germane at a time when, at least in Europe, agricultural subsidies and agri-environmental schemes are being critically reviewed and re-evaluated (Ovenden et al. 1998; Kleijn et al. 2001, 2004; Kleijn and Sutherland 2003).

Being essentially unstable plagioclimax communities, grasslands are especially vulnerable to abandonment or mismanagement. Recovery of species-rich grasslands can be attempted from three possible sources (Mortimer et al. 1998; Hutchings and Stewart 2002): re-creation from formerly cultivated land, reclamation from scrub, and restoration from species-poor, intensivelymanaged grassland. Success rates are low and variable between taxonomic groups. Restoration of a visually attractive plant community does not necessarily ensure a diversity of invertebrates, especially those with limited powers of dispersal. Preliminary evidence from calcareous grasslands suggest that ex-arable restoration schemes are colonized by leafhopper species that are common and widespread, but not by the rare specialist species that have poor mobility (Stewart, unpublished data). More work is needed on whether this is a general pattern and how it can be modified by appropriate site and landscape management.

There is now a substantial body of information about the biogeography, rarity status, habitat associations, host plants and life-history strategies of most grassland leafhopper species, at least in Europe (Nickel 2003). However, much remains to be learnt about the factors that drive population change in single species and that control the structure and composition of whole assemblages. There is an urgent need to bring together the substantial amount of widely-dispersed information that already exists for different geographic areas and for areas under different environmental management systems. Synthesis of such data could provide important new insights on how the structure and functioning of populations and assemblages changes along major environmental and land-use intensity gradients. This could be achieved within the European context where major environmental gradients (north-south, east-west, maritime-continental, lowland-upland) are overlain by gradients in anthropogenic influence (low intensity farming systems in eastern Europe through to highly fragmented semi-natural habitats within intensive agricultural landscapes in western Europe). Understanding how interactions between these influences affects leafhoppers could allow prediction of the effects of expected future changes in land use and climate. The approach could also become a model for studies on other taxa and other biogeographic regions.

\section{References}

Achtziger R. 1995. Die Struktur von Insektengemeinschaften an Gehölzen: Die Hemipteren-Fauna als Beispiel für die Biodiversität von Hecken und Waldrandökosystemen. Bayreuther Forum Ökologie (bfö) 20: 216.

Achtziger R. 1997. Organization patterns in a tritrophic plantinsect system: Hemipteran communities in hedges and forest margins. In: Dettner K., Bauer G. and Völkl W. (eds), Vertical Food Web Interactions - Evolutionary Patterns and Driving Forces. Springer, Heidelberg, pp. 277-297.

Achtziger R. 1999. Möglichkeiten und Ansätze des Einsatzes von Zikaden in der Naturschutzforschung. Reichenbachia 33: 171-190.

Ainouche M.L., Baumel A., Salmon A. and Yannic G. 2004. Hybridization, polyploidy and speciation in Spartina (Poaceae). New Phytologist 161: 165-172.

Alexander K.N.A. 2003. A review of the invertebrates associated with lowland calcareous grassland. English Nature Research Report 512.

Andrzejewska L. 1962. Macrosteles laevis Rib. as an unsettlement index of natural meadow associations of Homoptera. Bull. Acad. Sci. Cl. II. Ser. Sci. Biol. 10: 221-226.

Andrzejewska L. 1965. Stratification and its dynamics in meadow communities of Auchenorrhyncha (Homoptera). Ekol. Pol. Ser. A. 13: 685-715.

Andrzejewska L. 1979a. Herbivorous fauna and its role in the economy of grassland ecosystems. I. Herbivores in natural and managed meadows. Pol. Ecol. Stud. 5: 5-44.

Andrzejewska L. 1979b. Herbivorous fauna and its role in the economy of grassland ecosystems. II. The role of herbivores in trophic relationships. Pol. Ecol. Stud. 5: 45-76.

Andrzejewska L. 1991. Formation of Auchenorrhyncha communities in diversified structures of agricultural landscape. Pol. Ecol. Stud. 17: 267-287.

Asteraki, E.J., Hart, B.J., Ings, T.C., Manley and W.J. 2004. Factors influencing the plant and invertebrate diversity of arable field margins. Agric. Ecosyst. Environ. 102: 219-231.

Bale J.S., Masters G.J., Hodkinson I.D., Awmack C., Bezemer T.M., Brown V.K., Butterfield J., Buse A., Coulson J.C., 
Farrar J., Good J.E.G., Harrington R., Hartley S., Jones T.H., Lindroth R.L., Press M.C., Symrnioudis I., Watt A.D. and Whittaker J.B. 2002. Herbivory in global climate change research: direct effects of rising temperature on insect herbivores. Global Change Biol. 8: 1-16.

Biedermann R. 2000. Metapopulation dynamics of the froghopper Neophilaenus albipennis (F., 1798) (Homoptera, Cercopidae) - what is the minimum viable metapopulation size? . J. Insect Conserv. 4: 99-107.

Biedermann R. 2002. Leafhoppers (Hemiptera, Auchenorrhyncha) in fragmented habitats. Denisia 4: 523-530.

Biedermann R. 2004. Patch occupancy of two hemipterans sharing a common host plant. J. Biogeogr. 31: 1179-1184.

Biedermann R. and Niedringhaus R. 2004. Die Zikaden Deutschlands. Bestimmungstafeln für alle Arten. WABV Verlag, Scheeßel.

Bobbink R., Hornung M. and Roelofs J.G.M. 1998. The effects of air-borne nitrogen pollutants on species diversity in natural and semi-natural European vegetation. J. Ecol. 86: 717738.

Bouchard P., Hamilton K.G.A. and Wheeler T.A. 2001. Diversity and conservation status of prairie endemic Auchenorrhyncha (Homoptera) in alvars of the Great Lakes region. Proc. Entomol. Soc. Ontario 132: 39-56.

Brooks G.L. and Whittaker J.B. 1999. Responses of three generations of a xylem-feeding insect, Neophilaenus lineatus (Homoptera), to elevated $\mathrm{CO}_{2}$. Global Change Biol. 5: 395401.

Brown V.K., Gibson C.W.D. and Kathirithamby J. 1992. Community organization in leaf hoppers. Oikos 65: 97-106.

Chambers BQ and Samways MJ. 1998. Grasshopper response to a 40-year experimental burning and mowing regime, with recommendations for invertebrate conservation management. Biodiv. Conserv. 7: 985-1012.

Cherrill A.J. and Sanderson R.A. 1994. Comparison of sweepnet and pitfall trap samples of moorland Hemiptera: evidence for vertical stratification within vegetation. Entomologist 113: $70-81$.

Cronin J.T. 2004. Host-parasitoid extinction and colonization in a fragmented landscape. Oecologia 139: 503-514.

Crosby A. 1986. Ecological Imperialism: The Biological Expansion of Europe, 900-1900. Cambridge University Press, Cambridge.

Curry J.P. 1994. Grassland Invertebrates. Ecology, Influence on Soil Fertility and Effect on Plant Growth. Chapman \& Hall, London.

Davis A.J., Lawton J.H., Shorrocks B. and Jenkinson L.S. 1998. Individualistic species responses invalidate simple physiological models of community dynamics under global environmental change. J. Animal Ecol. 76: 600-612.

den Bieman C.F.M. 1987. Host plant relations in the planthopper genus Ribautodelphax (Homoptera: Delphacidae). Ecol. Entomol. 12: 163-172.

Denno R.F. 1994. Influence of habitat structure on the abundance and diversity of planthoppers. In: Denno R.F. and Perfect T.J. (eds), Planthoppers - Their Ecology and Management. Chapman \& Hall, London, pp. 140-160.

Denno R.F. and Perfect J.T. 1994. Planthoppers: Their Ecology and Management. Chapman \& Hall, New York.

Denno R.F., Peterson M.A., Gratton C., Cheng J., Langellotto G.A., Huberty A.F. and Finke D.L. 2000. Feeding-induced changes in plant quality mediate interspecific competition between sap-feeding herbivores. Ecology 81: 1814-1827.

Denno R.F. and Roderick G.K. 1991. Influence of patch size, vegetation texture, and host plant architecture on the diversity, abundance, and life history styles of sapfeeding herbivores. In: Bell S.S., McCoy E.D. and Mushinsky H.R. (eds), Habitat Structure - The Physical Arrangement of Objects in Space. Chapman \& Hall, London, pp. 169-196.

Denno R.F., Roderick G.K., Olmstead, K.L. and Doble H.G. 1991. Density-related migration in planthoppers (Homoptera: Delphacidae): the role of habitat persistence. Am. Nat. 138: 1513-1541.

Di Castri F., Hansen A.J. and Debussche M. 1990. Biological Invasions in Europe and the Mediterranean Basin. Kluwer, Dordrecht.

Dolling W.R. 1991. The Hemiptera. Oxford University Press, Oxford.

Drake J.A., Mooney H.A., di Castri F., Groves R.H., Kruger F.J., Rejmanek M. and Williamson M. 1989. Biological Invasions: A Global Perspective. John Wiley \& Sons, New York.

Erhardt A. and Thomas J.A. 1991. Lepidoptera as indicators of change in the semi-natural grasslands of lowland and upland Europe. In: Collins N.M. and Thomas J.A. (eds), The Conservation of Insects and Their Habitats. Academic Press, London, pp. 213-236.

Eyre M.D., Luff M.L. and Woodward J.C. 2003. Grouse moor management: habitat and conservation implications for invertebrates in southern Scotland. J. Insect Conserv. 7: 21-32.

Eyre M.D., Woodward J.C. and Luff M.L. 2001. The distribution of grassland Auchenorrhyncha assemblages (Homoptera: Cercopidae, Cicadellidae, Delphacidae) in northern England and Scotland. J. Insect Conserv. 5: 37-45.

Fielding C.A., Whittaker J.B., Butterfield J.E.L. and Coulson J.C. 1999. Predicting responses to climate change: the effect of altitude and latitude on the phenology of the spittlebug Neophilaenus lineatus. Funct. Ecol. 13(Suppl. 1): 65-73.

Gärdenfors U. 2000. Rödlistade arter i Sverige - The 2000 Red List of Swedish Species. SLU Uppsala, ArtDatabanken.

Gibson C.W.D., Brown V.K., Losito L. and McGavin G.C. 1992. The response of invertebrate assemblies to grazing. Ecography 15: 166-176.

Guglielmino G. and Olmi M. 1997. A host-parasite catalog of world Dryinidae (Hymenoptera: Chrysidoidea). Contributions Entomol. Int. 2: 164-298.

Haddad N.M., Haarstad J. and Tilman D. 2000. The effects of long-term nitrogen loading on grassland insect communities. Oecologia 124: 73-84.

Hamilton K.G.A. 1983. Introduced and native leafhoppers common to the Old and New Worlds (Rhynchota: Homoptera: Cicadellidae). Can. Entomol. 115: 473-511.

Harrington R., Woiwod I. and Sparks T. 1999. Climate change and trophic interactions. Trends Ecol. Evol. 14: 146-150.

Harrison S. and Bruna E. 1999. Habitat fragmentation and large-scale conservation: what do we know for sure? Ecography 22: 225-232.

Hollier J.A., Brown V.K. and Edwards-Jones G. 1994. Successional leafhopper assemblages: pattern and process. Ecol. Res. 9: 185-191.

Holzinger W.E. 1999. Rote Liste der Zikaden Kärntens (Insecta: Auchenorrhyncha). In: Rottenburg T., Wieser C., 
Mildner P. and Holzinger W.E. (eds), Rote Listen gefährdeter Tiere Kärntens. Naturschutz in Kärnten 15, pp. 425-450.

Holzinger W.E., Kammerlander I. and Nickel H. 2003. The Auchenorrhyncha of Central Europe - Die Zikaden Mitteleuropas. Vol. 1: Fulgoromorpha, Cicadomorpha excl Cicadellidae. Brill Academic Publishers, Leiden.

Hughes L. 2000. Biological consequences of global warming: is the signal already apparent? TREE 15: 56-61.

Hutchings M.J. and Stewart A.J.A. 2002. Calcareous grasslands. In: Davy A.J. and Perrow M.R. (eds), Handbook of Ecological Restoration Volume 2: Restoration in Practice, pp. 419-442.

Huusela-Veistola E. and Vasarainen A. 2000. Plant succession in perennial grass strips and effects on the diversity of leafhoppers (Homoptera, Auchenorrhyncha). Agric. Ecosyst. Environ. 80: 101-112.

Huxel G.R. and Hastings A. 1999. Habitat loss, fragmentation, and restoration. Restor. Ecol. 7: 309-315.

IUCN 2004. IUCN Red List of Threatened Species. www.redlist.org. Downloaded on 30 November 2004

Karban R. and Strauss S.Y. 2004. Physiological tolerance, climate change, and anorthward range shift in the spittlebug, Philaenus spumarius. Ecol. Entomol. 29: 251-254.

Kowarik I. 2003. Biologische Invasionen. Neophyten und Neozoen in Mitteleuropa. Ulmer, Stuttgart, pp. 380.

Kirby P. 1992. A Review of the Scarce and Threatened Hemiptera of Great Britain. UK Nature Conservation, No. 2

Kirby P., Stewart A.J.A. and Wilson M.R. 2001. True bugs, leaf- and planthoppers and their allies. In: Hawksworth D.L. (eds), The Changing Wildlife of Great Britain and Ireland. Taylor \& Francis, London, pp. 262-299.

Kleijn D., Berendse F., Smit R. and Gilissen N. 2001. Agrienvironment schemes do not effectively protect biodiversity in Dutch agricultural landscapes. Nature 413: 723-725.

Kleijn D., Berendse F., Smit R., Gilissen N., Smit J., Brak B. and Groeneveld R. 2004. Ecological effectiveness of agrienvironment schemes in different agricultural landscapes in the Netherlands. Conserv. Biol. 18: 775-786.

Kleijn D. and Sutherland W.J. 2003. How effective are European agri-environment schemes in conserving and promoting biodiversity? J. Appl. Ecol. 40: 947-969.

Kontkanen P. 1950. Quantitative and seasonal studies on the leafhopper fauna of the field stratum on open areas in North Karelia. Suomal. eläin- ja kasvit. Seur. van. Julk. 13: 1-91.

Kruess A. and Tscharntke T. 2002. Contrasting responses of plant and insect diversity to variation in grazing intensity. Biol. Conserv. 106: 293-302.

Maramorosch K. and Harris K.F. 1979. Leafhopper Vectors and Plant Disease Agents. Academic Press, New York.

Masters G.J., Brown V.K., Clarke I.P., Whittaker J.B. and Hollier J.A. 1998. Direct and indirect effects of climate change on insect herbivores: Auchenorrhyncha (Homoptera). Ecol. Entomol. 23: 45-52.

Mattson W.J. 1980. Herbivory in relation to plant nitrogen content. Annu. Rev. Ecol. Syst. 11: 119-161.

Mooney H.A. and Hobbs R.J. 2000. Invasive Species in a Changing World. Island Press, Washington/Covelo.

Moreby S.J. and Stoate C. 2001. Relative abundance of invertebrate taxa in the nestling diet of three farmland passerine species, Dunnock Prunella modularis, Whitethroat Sylvia communis and Yellowammer Emberiza citrinella in Leicestershire, England. Agric. Ecosyst. Environ. 86: 125-134.

Mortimer S.R., Hollier J.A. and Brown V.K. 1998. Interactions between plant and insect diversity in the restoration of lowland calcareous grasslands in southern England. Appl. Veget. Sci. 1: 101-114.

Morris M.G. 1971. Differences between the invertebrate faunas of grazed and ungrazed chalk grassland. IV. Abundance and diversity of Homoptera-Auchenorrhyncha. J. Appl. Ecol. 8: $37-52$.

Morris M.G. 1973. The effects of seasonal grazing on the Heteroptera and Auchenorrhyncha (Hemiptera) of chalk grassland. J. Appl. Ecol. 10: 761-780.

Morris M.G. 1975. Preliminary observations on the effects of burning on the Hemiptera (Heteroptera and Auchenorrhyncha) of limestone grassland. Biol. Conserv. 7: 311-319.

Morris M.G. 1981a. Responses of grassland invertebrates to management by cutting III. Adverse effects on Auchenorrhyncha. J. Appl. Ecol. 18: 107-123.

Morris M.G. 1981b. Responses of grassland invertebrates to management by cutting. IV. Positive responses of Auchenorrhyncha. J. Appl. Ecol. 18: 763-771.

Morris M.G. 1990. The Hemiptera of two sown calcareous grasslands. II. Differences between treatments. J. Appl. Ecol. 27: 379-393.

Morris M.G. 1992. Responses of Auchenorrhyncha (Homoptera) to fertiliser and liming treatments at Park Grass, Rothamsted. Agric. Ecosyst. Environ. 41: 263-283.

Morris M.G. 2005. The success of a rotational grazing system in conserving the diversity of chalk grassland Auchenorrhyncha. J. Insect Conserv.(this issue)

Murdoch W.M., Evans F.C. and Peterson C.H. 1972. Diversity and patterns in plants and insects. Ecology 53: 819-829.

Nault L.R. and Rodriguez J.G. 1985. The Leafhoppers and Planthoppers. Wiley, New York.

New T.R. 1995. An Introduction to Invertebrate Conservation Biology. Oxford Science Publications, Oxford.

Nickel H. 2003. The Leafhoppers and Planthoppers of Germany (Hemiptera, Auchenorrhyncha): Patterns and Strategies in a Highly Diverse Group of Phytophagous Insects. Pensoft, Sofia/Moscow.

Nickel H. 2004. Rote Liste gefährdeter Zikaden (Hemiptera, Auchenorrhyncha) Bayerns. Schriftenreihe des Bayerischen Landesamtes für Umweltschutz 166: 59-67.

Nickel H. and Achtziger R. 1999. Wiesen bewohnende Zikaden (Auchenorrhyncha) im Gradienten von Nutzungsintensität und Feuchte. Beiträge zur Zikadenkunde 3: 65-80.

Nickel H. and Achtziger R. 2005. They never come back? Responses of leafhopper and planthopper communities to grassland restoration J. Insect Conserv.(this issue)

Nickel H. and Hildebrandt J. 2003. Auchenorrhyncha communities as indicators of disturbance in grasslands (Insecta, Hemiptera) - a case study from the Elbe flood plains (northern Germany). Agric. Ecosyst. Environ. 98: 183-199.

Nickel H. and Sander F.W. 2001. Rote Liste der Zikaden (Hemiptera: Auchenorrhyncha) Thüringens. 3. Fassung, Stand: 08/2001. Naturschutzreport 19: 87-94.

Nickel H., Witsack W. and Remane R. 1999. Rote Liste der Zikaden Deutschlands (Hemiptera, Auchenorrhyncha) Habitate, Gefährdungsfaktoren und Anmerkungen zum Areal. Beiträge zur Zikadenkunde 3: 13-32. 
Niedringhaus R. 1999. Bewertung des Renaturierungserfolges in einer Agrarlandschaft Nordwestdeutschlands anhand der Zikadenfauna (Auchenorrhyncha). Beiträge zur Zikadenfauna 3: 49-64.

Nikusch I. 1976. Untersuchungen über die Zikadenfauna (Homoptera - Auchenorrhyncha) des Vogelsberges. Jb. nass. Ver. Naturk. 103: 98-166.

Novotný V. 1991. Responses of Auchenorrhyncha community to selected characteristics of littoral and meadow vegetation. Ekológia (CSFR) 10: 271-282.

Novotný V. 1994a. Relation between temporal persistence of host plants and wing length in leafhoppers (Hemiptera: Auchenorrhyncha). Ecol. Entomol. 19: 168-176.

Novotný V. 1994b. Association of polyphagy in leafhoppers (Auchenorrhyncha, Hemiptera) with unpredictable environments. Oikos 70: 223-232.

Oates M.R. 1995. Butterfly conservation within the management of grassland habitats. In: Pullin A.J. (ed), Ecology and Conservation of Butterflies. Chapman \& Hall, London.

Ovenden GN, Swash ARH and Smallshire D. 1998. Agrienvironment schemes and their contribution to the conservation of biodiversity in England. J. Appl. Ecol. 35: 955-960.

Panzer R. and Schwartz M. 2000. Effects of management burning on prairie insect species richness within a system of small, highly fragmented reserves. Biol. Conserv. 96: 363369.

Payne K.R. 1981. A comparison of the catches of Auchenorrhyncha (Homoptera) obtained from sweep netting and pitfall trapping. Entomol. Monthly Mag. 117: 215-223.

Prestidge R.A. 1982. The influence of nitrogenous fertilizer on the grassland Auchenorrhyncha (Homoptera). J. Appl. Ecol. 19: 735-749.

Prestidge R.A. and McNeil S. 1982. The role of nitrogen in the ecology of grassland Auchenorrhyncha. In: Lee J.A., McNeil S. and Rorison I.H. (eds), Nitrogen as an Ecological Factor, Symposium of the British Ecological Society, 22. Blackwell Scientific Publications, Oxford, pp. 257-281.

Raatikainen M. 1967. Bionomics, enemies and population dynamics of Javesella pellucida (F.) (Hom., Delphacidae). Annales Agriculturae Fenniae 6: 1-147.

Remane R. 1994. Rote Liste der gefährdeten Kleinzikaden (Auchenorrhyncha: Cicadina) Südtirols. In: Amt für Landschaftsplanung and Autonome Provinz Bozen/Südtirol (eds), Rote Liste gefährdeter Tierarten Südtirols. Bozen, pp. 312321.

Remane R., Achtziger R., Fröhlich W., Nickel H. and Witsack W. 1998. Rote Liste der Zikaden (Homoptera, Auchenorrhyncha). In: Binot M., Bliss R., Boye P., Gruttke H. and Pretscher P. (eds), Rote Liste der gefährdeten Tiere Deutschlands. Schriftenreihe für Landschaftspflege und Naturschutz 55, pp. 312-321.

Remane R. and Wachman E. 1993. Zikaden: kennenlernen beobachten. Naturbuch Verlag, Augsburg.

Rothschild G.H.L. 1966. A study of natural population of Conomelus anceps (Germar) (Homoptera: Delphacidae) including observations on predation using the precipitin test. J. Anim. Ecol. 35: 413-434.

Samways M.J. 2005. Insect Diversity Conservation. Cambridge University Press, Cambridge.

Schedl W. 1994. Rote Liste der gefährdeten Sing- und Buckelzikaden (Cicadidae, Tibicinidae und Membracidae)
Südtirols. In: Amt für Landschaftsplanung and Autonome Provinz Bozen/Südtirol (eds), Rote Liste gefährdeter Tierarten Südtirols, jfkgfk. Bozen, pp. 308-311.

Sedlacek J.D., Barrett G.W. and Shaw D.R. 1988. Effects of nutrient enrichment on the Auchenorrhyncha (Homoptera) in contrasting grassland communities. J. Appl. Ecol. 25: 537550.

Seljak G. 2004. Prokelisia marginata (Van Duzee, 1897) - a Nearctic planthopper new to Slovenia and Europe (Auchenorrhyncha: Delphacidae). Acta Entomologica Slovenica 12: $260-263$.

Settle W.H. and Wilson L.T. 1990. Invasion by the variegated leafhopper and biotic interactions: parasitism, competition, and apparent competition. Ecology 71: 1461-1470.

Settele J., Margules C., Poschlod P. and Henle K. 1996. Species Survival in Fragmented Landscapes. Kluwer, Dordrecht.

Siemann E., Tilman D. and Haarstad J. 1996. Insect species diversity, abundance and body size relationships. Nature 380: 704-706.

Siemann E., Tilman D. and Haarstad J. 1999. Abundance, diversity and body size: patterns from a grassland arthropod community. J. Appl. Ecol. 68: 824-835.

Stewart A.J.A. 1999. Twenty years of recording the distribution of Auchenorrhyncha in Britain and Ireland: progress, achievements and prospects. Reichenbachia 33: 207-214.

Stewart A.J.A. 2002. Techniques for sampling Auchenorrhyncha in grasslands. Denisia 4: 491-512.

Thomas J.A. 1983. The ecology and conservation of Lysandra bellargus (Lepidoptera: Lycaenidae) in Britain. J. Appl. Ecol. 20: 59-83.

Thompson P. 1978. The oviposition sites of five leafhopper species (Homoptera, Auchenorrhyncha) on Holcus mollis and H. lanatus. Ecol. Entomol. 3: 231-240.

Tonkyn D.W. and Whitcomb R.F. 1987. Feeding strategies and the guild concept among vascular feeding insects and microorganisms. Curr. Top. Vector Res. 4: 179-199.

Tscharntke T. and Greiler H.-J. 1995. Insect communities, grasses, and grasslands. Annu. Rev. Entomol. 40: 535-558.

Tscharntke T. and Brandl R. 2004. Plant-Insect interactions in fragmented landscapes. Annu. Rev. Entomol. 49: 405-430.

Voigt W., Perner J., Davis A.J., Eggers T., Schumacher J., Bahrmann R., Fabian B., Heinrich W., Kohler G., Lichter D., Marstaller R. and Sander F.W. 2003. Trophic levels are differentially sensitive to climate. Ecology 84: 2444-2453.

Waloff N. 1975. The parasitoids of the nymphal and adult stages of leafhoppers (Auchenorrhyncha: Homoptera) of acidic grassland. Trans. R. Ent. Soc. London 126: 637-686.

Waloff N. 1980. Studies on grassland leafhoppers and their natural enemies. Adv. Ecol. Res. 11: 81-215.

Waloff N. and Jervis M.A. 1987. Communities of parasitoids associated with leafhoppers and planthoppers in Europe. Adv. Ecol. Res. 17: 281-402.

Waloff N. and Solomon M.G. 1973. Leafhoppers (Auchenorrhyncha: Homoptera) of acidic grassland. J. Appl. Ecol. 10: 189-212.

Waloff N. and Thompson P. 1980. Census data and analyses of populations of some leafhoppers (Auchenorrhyncha, Homoptera) of acidic grassland. J. Animal Ecol. 49: 395-416.

Walter S., Emmrich R. and Nickel H. 2003. Rote Liste der Zikaden Sachsens. Stand 2003. Materialien zu Naturschutz 
und Landschaftspflege 2003. Freistaat Sachsen, Landesamt für Umwelt und Geologie.

Whitcomb R.F., Hicks A.L., Blocker H.D. and Lynn D.E. 1994. Biogeography of leafhopper specialists of the shortgrass prairie. Am. Entomol. 40: 19-35.

White T.C.R. 1993. The Inadequate Environment. Nitrogen and the Abundance of Animals. Springer, Berlin.

Whittaker J.B. 1969. Quantitative and habitat studies of the froghoppers and leafhoppers (Homoptera, Auchenorrhyncha) of Wytham Woods, Berkshire. Entomol. Monthly Mag. 105: 27-37.

Whittaker J.B. 1971. Population changes in Neophilaenus lineatus (L.) (Homoptera: Cercopidae) in different parts of its range. J. Animal Ecol. 40: 425-443.

Whittaker J.B. 1973. Density regulation in a population of Philaenus spumarius (L.) (Homoptera: Cercopidae). J. Animal Ecol. 42: 163-172.
Whittaker J.B. and Tribe N.P. 1996. An altitudinal transect as an indicator of responses of a spittlebug (Auchenorrhyncha: Cercopidae) to climate change. Eur. J. Entomol. 93: 319-324. Whittaker J.B. and Tribe N.P. 1998. Predicting numbers of an insect (Neophilaenus lineatus: Homoptera) in a changing climate. J. Animal Ecol. 67: 987-991.

Wilson E.J., Wells T.C.E. and Sparks T.H. 1995. Are calcareous grasslands in the UK under threat from nitrogen deposition?- an experimental determination of a critical load. J. Ecol. 83: 823-832.

Witsack W. 1995. Rote Liste der Zikaden des Landes SachsenAnhalt. Ber. LA Umweltsch. Sachsen-Anhalt 18: 29-34. 